\title{
Gastrointestinal tuberculosis: a diagnosis not to miss
}

\author{
${ }^{1}$ A Manuel, ${ }^{2} \mathrm{Z}$ Lim, ${ }^{3} \mathrm{~J}$ Wiggins \\ ${ }^{1}$ Specialist Trainee 4 in Respiratory Medicine; ${ }^{2}$ Core Medical Trainee; ${ }^{2}$ Consultant Respiratory Physician, Respiratory Department, Wexham \\ Park Hospital, Slough, Berkshire, UK
}

ABSTRACT Gastrointestinal tuberculosis is not rare but may present to the clinician in a variety of ways, leading to confusion with several other diseases. It is crucial to send tissue samples for culture.

KEYWORDS Abdominal, gastrointestinal, tuberculosis

DECLARATION OF INTERESTS No conflict of interests declared.
Correspondence to A Manuel, Respiratory Department, Wexham Park Hospital, Slough SL2 4HL, UK

tel. $+44(0) 1753633000$ e-mail arimanuel1979@yahoo.co.uk

\section{INTRODUCTION}

Tuberculosis (TB) is still a major public health issue. It causes approximately three million deaths worldwide annually and its incidence continues to increase. Tuberculosis can affect the entire gastrointestinal tract, including the liver, spleen and pancreas.' Tuberculosis infection within the abdomen confers a significant degree of morbidity and mortality of all cases, comprising up to $12 \%$ of extra pulmonary TB and I-3\% of the total.' It can often mimic many gastrointestinal diseases, especially inflammatory bowel disease, which may result in delayed and inappropriate treatment. We report a case series that presented recently to a district general hospital. Many of these cases presented to surgical colleagues and in a number the initial working diagnosis was incorrect. These cases illustrate the breadth of TB presentation and its wide variety of clinical features. It is important that all clinicians continue to remember that TB is a potential diagnosis in all patients presenting with features of gastrointestinal disease and that it is treatable.

\section{METHODS}

A group of patients treated for abdominal tuberculosis was identified from local notification to the Health Protection Agency between January 2008 and August 2009. A retrospective review of these case notes was performed. Data collected included demographic data, clinical presentation, diagnostic investigations, treatment and outcome.

\section{RESULTS}

Sixteen patients were diagnosed with gastrointestinal TB during this period (Table I). The median age of presentation was 39 years (range 23-86). There were six males and ten females.The ethnic origins of the patients included 12 South Asians, one African and three Caucasians; one had no previous known exposure to TB.
Presenting complaints varied. A prominent symptom was abdominal pain. This varied in both duration and character. Four (25\%) of the patients presented with symptoms suggestive of an acute abdomen, while in a further eight (50\%) the pain was chronic and the patients were investigated as outpatients. Other symptoms included fever, weight loss, vomiting, change in bowel habit and abdominal swelling due to ascites (one patient).

There were two atypical presentations. Patient 15 was an 84-year-old Caucasian female who presented with a six-month history of weight loss and microcytic anaemia. Initially a decision was made with the patient for no further investigation as it was thought most likely to reflect an underlying colonic malignancy. However, the patient represented to the surgeons with an acute obstruction and a colonoscopic biopsy showed subsequent histology and microbiology consistent with a tuberculous ulcer. Patient 16 was an 86-year-old Caucasian male who presented with a six-month history of weight loss and altered bowel habit. Colonoscopy revealed two obstructing lesions that were initially thought to be synchronous tumours. However, one of the lesions subsequently turned out to be a tuberculous ulcer.

Physical signs were often non-specific and generally unhelpful. One patient presented with lymphadenopathy and there were no presentations with hepatosplenomegaly. Three patients presented with fevers. None of the patients presented with an abdominal mass or the 'doughy abdomen' said to be characteristic of omental TB.

In terms of common investigations, no test was specific or discriminating. The C-reactive peptide level was normal $(<7 \mathrm{mg} / \mathrm{l})$ in six $(38 \%)$ of the cases, with an average of $70 \mathrm{mg} / \mathrm{l}$ (range 3-205). The erythrocyte sedimentation rate (ESR) was measured in 15 patients, with six (38\%) patients having an ESR of $<50 \mathrm{~mm} /$ hour and an average of $55 \mathrm{U} / \mathrm{l}$ (range 15-136). The alkaline phosphatase was normal in eight $(50 \%)$ patients, with an average of 150 (range 8I-330). The white blood count 
TABLE I Summary of individual cases

\begin{tabular}{|c|c|c|c|c|c|}
\hline $\begin{array}{l}\text { Case } \\
\text { index }\end{array}$ & Age & $\begin{array}{l}\text { Characteristics of } \\
\text { abdominal pain }\end{array}$ & $\begin{array}{l}\text { Systemic } \\
\text { features }\end{array}$ & $\begin{array}{l}\text { Other } \\
\text { features }\end{array}$ & Positive imaging results \\
\hline 1 & 23 & Nil & $\begin{array}{l}\text { Weight loss } \\
\text { and fever }\end{array}$ & Nil & $\begin{array}{l}\text { Omental caking. Small amount of ascites. } \\
\text { Splenomegaly. Necrotic nodule anterior to } \\
\text { liver. 6-mm nodule in RUZ }\end{array}$ \\
\hline 2 & 24 & $\begin{array}{l}\text { Epigastric pain and right upper } \\
\text { quadrant tenderness for years } \\
\text { with appendicular mass }\end{array}$ & Nil & Nil & $\begin{array}{l}\text { 6-cm mass from terminal ileum. Inflammatory } \\
\text { changes in peritoneum. Few enlarged LNs }\end{array}$ \\
\hline 3 & 26 & Vague epigastric pain & Nil & $\begin{array}{l}\text { Petechial } \\
\text { rash and low } \\
\text { platelet count }\end{array}$ & $\begin{array}{l}\text { Necrotic lymph nodes associated with } 4.5-\mathrm{cm} \\
\text { tumour in pancreatic head.Thickened loop of } \\
\text { bowel. Ring-enhancing lesions in subcarina }\end{array}$ \\
\hline 4 & 26 & Nil & $\begin{array}{l}\text { Weight loss } \\
\text { and vomiting }\end{array}$ & $\begin{array}{l}\text { Change in } \\
\text { bowel habit }\end{array}$ & Caseating lymphadenopathy \\
\hline 5 & 28 & $\begin{array}{l}\text { Right iliac fossa pain leading to } \\
\text { appendicectomy. Re-admitted } \\
\text { with wound discharge }\end{array}$ & Nil & Nil & $\begin{array}{l}\text { Focal enhancement of the appendix with } \\
\text { inflammatory changes surrounding caecum }\end{array}$ \\
\hline 6 & 28 & $\begin{array}{l}\text { Acute abdominal pain and } \\
\text { nausea }\end{array}$ & Nil & Nil & $\begin{array}{l}\text { Lymphadenopathy, ascites and peritoneal } \\
\text { disease. Scarring upper zones }\end{array}$ \\
\hline 7 & 28 & $\begin{array}{l}\text { Abdominal pain, vomiting and } \\
\text { weight loss }\end{array}$ & Nil & Nil & No CT done \\
\hline 8 & 32 & $\begin{array}{l}\text { Lower abdominal pain and } \\
\text { dyspareunia }\end{array}$ & Weight loss & $\begin{array}{l}\text { Per vaginal } \\
\text { bleeding }\end{array}$ & No CT done \\
\hline 9 & 33 & $\begin{array}{l}5 \text { months of intermittent } \\
\text { abdominal pain }\end{array}$ & $\begin{array}{l}\text { Weight loss } \\
\text { and fever }\end{array}$ & Nil & $\begin{array}{l}\text { Cavity in RUZ. Terminal ileum, ileocaecal } \\
\text { valve, appendix, ascending colon affected. Free } \\
\text { fluid in pelvis. Lymphadenopathy }\end{array}$ \\
\hline 10 & 34 & $\begin{array}{l}\text { Periumbilical pain shifting to } \\
\text { colicky right iliac fossa over } 4 / 7\end{array}$ & Nil & Nil & No CT done \\
\hline 11 & 35 & Nil & Nil & Ascites & Ascites. Paraphrenic nodes \\
\hline 12 & 35 & $\begin{array}{l}\text { Acute left upper quadrant } \\
\text { pain and vomiting }\end{array}$ & Nil & Nil & $\begin{array}{l}\text { Thickened terminal ileum, lymphadenopathy. } \\
\text { Old scarring on right apex }\end{array}$ \\
\hline 13 & 36 & I year of abdominal pain & $\begin{array}{l}\text { Weight loss } \\
\text { of } 20 \mathrm{~kg} \text { and } \\
\text { vomiting }\end{array}$ & Nil & $\begin{array}{l}\text { Multiple ring-enhancing } \mathrm{LN} \text { within } \\
\text { mesentery and retroperitoneum associated } \\
\text { with thickened caecum }\end{array}$ \\
\hline 14 & 57 & Intermittent abdominal pain & $\begin{array}{l}\text { I month fever } \\
\text { and weight loss }\end{array}$ & $\begin{array}{l}\text { Recent stay } \\
\text { in India }\end{array}$ & $\begin{array}{l}\text { Mediastinal LN with } 4.5-\mathrm{cm} \text { mass at hepatic } \\
\text { porta }\end{array}$ \\
\hline 15 & 84 & Nil & Nil & Nil & $\begin{array}{l}\text { Old upper lobes scarring. Lymphadenopathy } \\
\text { surrounding tumour in distal colon }\end{array}$ \\
\hline 16 & 86 & Non-specific abdominal pain & Weight loss & $\begin{array}{l}\text { Microcytic } \\
\text { anaemia }\end{array}$ & Caecal thickening \\
\hline
\end{tabular}

Abbreviations: $\mathrm{CT}$ = computed tomography; $\mathrm{LN}=$ lymph nodes; $\mathrm{RUZ}=$ right upper zone.

was normal in 14 patients (88\%), with a range of 4.8 $11.9 \times 10^{\%} / 1$. The chest radiograph was reported as abnormal in only five of the cases (32\%). All patients tested negative for human immunodefiency virus antibodies.

The Mantoux test was performed in six (38\%) cases and was positive in all of them. An interferon-gamma release assay (IGRA), Quantiferon-TB Gold, was performed in two cases; both were positive.

An abdominal ultrasound scan (USS) was performed in I3 patients, with six reported as essentially normal. The positive features were thickened ileum/appendix (two), ascites (one), thickened peritoneum (one), masses (one epigastric and one adnexal) and para-aortic lymphadenopathy (one).

A computed tomography (CT) scan of the abdomen was performed in 13 patients; in II the radiologists reported abnormalities suggestive of abdominal TB. However, one scan was reported to be consistent with a colonic tumour and another was thought to be pancreatic cancer.

Endoscopic procedures were performed in seven patients, with only two leading to the eventual diagnosis. 
Histology was obtained in nine patients (56\%), with only five of these patients having their samples sent for culture. In the remaining II patients, a clinical diagnosis was made supported by a positive response to a trial of anti-tuberculous chemotherapy. All patients were treated successfully with standard six-month quadruple chemotherapy (ethambutol, rifampicin, pyrazinamide and isoniazid for two months, followed by rifampicin and isoniazid for a further four months) and were well on completion of therapy.

\section{DISCUSSION}

These cases illustrate the spectrum of presentation of intra-abdominal TB in a district general hospital. They also raise several interesting points for discussion and emphasise the need to continually remember the possibility of TB when considering the differential diagnosis of patients presenting with a range of gastrointestinal problems, both in the acute and chronic setting. ${ }^{2}$

The reports show that, contrary to the available literature, gastrointestinal TB in our experience did not present in the usual manner. Furthermore, many patients did not have the usual systemic symptoms (fever and weight loss) associated with TB. Indeed, two cases were atypical, occurring in elderly Caucasians. Neither the presenting clinical features nor the results on routine investigations could be relied upon to discriminate and raise suspicion of the diagnosis. There were also no 'red flags' for abdominal TB, which can have both an exceptionally insidious course and an acute presentation.

The laboratory results were non-specific, as exemplified by the range of blood results, and it needs to be emphasised that normal inflammatory markers should not exclude consideration of underlying TB in a patient presenting with gastrointestinal problems. The presence of TB in the respiratory tract cannot be relied upon as a diagnostic pointer as chest imaging was frequently normal.

The cases reported mimicked a number of other diagnoses, including bowel malignancy, lympho-reticular disease and appendicitis. We have also seen cases which have proven difficult to distinguish from inflammatory bowel disease, as others have also reported. ${ }^{1-3}$ These cases support the need to confirm, whenever possible, all clinical diagnoses by either histology or, where relevant, microbiology, to avoid making serious errors. That this was not done in many of these cases probably reflects the fact that TB may no longer be included in the differential diagnosis of patients presenting with gastrointestinal problems, even in an area of the UK such as Slough, with a high ethnic minority population and where the local incidence of TB is relatively high. This must be an even greater danger in areas of low incidence of TB and continued adherence to best practice is necessary.
Tuberculin tests were positive in all patients tested, and Demir et al. ${ }^{4}$ obtained a positive result in all of their 26 patients. However, it needs to be pointed out to nonspecialists that neither the tuberculin test nor IGRAs are diagnostic investigations. Both suggest the presence of infection by the tubercle bacillus but cannot distinguish active from latent disease. The role of IGRAs in the diagnosis of TB in general may become more important with refinements in the test currently undergoing research (Lalvani A, personal communication) and the test may aid differential diagnosis and direct further investigation; for example, a recent report described the case of a 75-yearold man who presented with a right colonic mass and subsequently underwent right hemicolectomy. Preoperative laboratory, radiological and endoscopic evaluations were negative for $T B$, with only the Quantiferon-TB Gold test being positive. Subsequent surgical specimens showed non-caseating granulomas. ${ }^{5}$

Polymerase chain reaction (PCR) assays are currently employed as a laboratory tool, which has the theoretical potential to aid in the rapid diagnosis of TB. Progress has been made in this field with the identification of their role alongside other tests (cultures, Mantoux and IGRAs), but as yet PCR assays remain a research tool. ${ }^{6,7}$

The measurement of adenosine deaminases in both pleural and ascitic fluid has gained wide acceptance, but like PCR techniques, its use still requires further evaluation prior to recommending routine usage. ${ }^{8}$

A therapeutic trial of standard quadruple antituberculous drugs for a six-month regimen was used in many of these cases, with successful outcomes for all. This approach may be reasonable in patients who are unfit for invasive investigation, particularly in areas where resistance to anti-tuberculous chemotherapy is low. Only culture allows both a firm diagnosis and the availability of drug sensitivities. The diagnosis of TB in these patients relied heavily on a combination of imaging (CT and USS) and clinical judgement. The characteristic CT findings of gastrointestinal $\mathrm{TB}^{9}$ and features, enabling radiologists to distinguish between lymphoma and tuberculous lymphadenopathy, have been reported. ${ }^{10}$ However, it must be emphasised that imaging is never conclusive and should always be supported by other investigations.

\section{CONCLUSION}

The patients described here serve as a reminder that TB should still be considered in the differential diagnosis of patients presenting with a variety of gastrointestinal problems. All the patients in this case series had a successful clinical outcome, but in many the optimal tests to confirm diagnosis were not performed. In particular, surgically obtained tissue was not sent for culture. This is crucial for both security of diagnosis and the correct therapy, and should be remembered by all clinicians. 


\section{REFERENCES}

I Kapoor VK. Abdominal tuberculosis. Postgrad Med J 1998; 74:459-67. doi:I0.II36/pgmj.74.874.459

2 Gadwood KA, Bedetti CD, Herbert DL. Colonic tuberculosis mimicking annular carcinoma: report of a case. Dis Colon Rectum 1981; 24:395-8. doi:10.1007/BF02603427

3 King HC,Voss EC.Tuberculosis of the caecum simulating carcinoma. Dis Colon Rectum 1980; 23:49-53. doi:I0.1007/BF0258720I

4 Demir K, Okten A, Kaymakoglu S et al. Tuberculous peritonitis reports of 26 cases, detailing diagnostic and therapeutic problems. Eur J Gastroenterol Hepatol 200 I; I 3:58 I-5. doi: I 0. I097/00042737200105000-00019

5 Caputo D, Alloni R, Garberini A et al. Experience with two cases of intestinal tuberculosis: utility of the QuantiFERON-TB Gold test for diagnosis. Surg Infect 2008, 9:407-10. doi:10.1089/sur.2007.006

6 Louie M, Louie L, Simor AE. The role of DNA amplification technology in the diagnosis of infectious diseases. CMAJ 2000 163:301-9.
7 Takahashi T, Tamura, M, AsamiY et al. Novel wide-range quantitative nested real-time PCR assay for Mycobacterium tuberculosis DNA: development and methodology. J Clin Microbiol 2008; 46:1708-I5. doi:I0.I I28/JCM.0I200-07

8 Gopi A, Madhavan S, Sharma S et al. Diagnosis and treatment of tuberculous pleural effusion in 2006. Chest 2007; 131:880-9. doi: I0.1378/chest.06-2063

9 Epstein BM, Mann JH. CT of abdominal tuberculosis. AJR Am J Roentgenol 1982; I39:86I-6.

10 Dong P, Wang B, Sun QY et al.Tuberculosis versus non-Hodgkin's lymphomas involving small bowel mesentery: evaluation with contrast-enhanced computed tomography. World J Gastroenterol 2008; |4:39|4-8. doi:I0.3748/wjg. I4.39|4

\section{FORTHCOMING SYMPOSIA 2010 \& $201 \mathrm{I}$}

\section{0}

- Diabetes and endocrinology:

Learning from other specialists

7 October

- Trainees \& Members' Committee Symposium:

When tomorrow comes - delivering medicine

for the future

22 October

Neurology

27 October

Renal medicine (SRA/RCPE joint event)

5-6 November

I 6th Anniversary Preston Symposium:

Advances in medicine - exploring new frontiers

10 November

Gastroenterology

II November

Cardiology

23 November

50th St Andrew's Day Festival:

Five decades of medical progress

2-3 December

\section{1}

Dundee Symposium: Moving points in medicine 9 February

Respiratory medicine 4 March

Public health

10 March

Palliative care (RCPE/RCGP joint symposium) 28 March

Care of the elderly (RCPE/RCGP joint symposium)

Haematology

5 May

Maternal medicine

2 June

Infectious diseases

16 June

Looking ahead, the College is planning its next Consensus Conference, on Atrial Fibrillation, for I-2 March 2012.
All symposia are held at the Royal College of Physicians of Edinburgh unless otherwise stated. Further symposia may be added at a later date.

Programme details at: http://events.rcpe.ac.uk or contact the Symposium Co-ordinator: Tel: 0I3। 2257324

Email: e.strawn@rcpe.ac.uk

Webstreamed Lectures If you are unable to attend symposia at the College in Edinburgh, selected lectures from all symposia are available to view and listen to at the Online Education section of the secure area of the College website. There are currently more than 100 lectures covering all the medical specialties and a range of generic topics.

\section{Book online at} http://events.rcpe.ac.uk 